\title{
EGFR Antisense DNA
}

National Cancer Institute

\section{Source}

National Cancer Institute. EGFR Antisense DNA. NCI Thesaurus. Code C2617.

A synthetic sequence of DNA constructed in the antisense orientation to a sequence of DNA in epidermal growth factor receptor (EGFR), a member of the erbB gene family. EGFR antisense DNA suppresses the expression of EGFR by tumor cells, thereby inhibiting tumor cell proliferation and decreasing tumor growth. This agent also appears to reduce the invasiveness of certain breast cancer cells. Members of the erbB gene family are overexpressed in many cancers and play roles in carcinogenesis and the regulation of cell proliferation. ( $\mathrm{NCl} 04)$ 